\title{
Digital Transformation of the Agro-industrial Complex in Russia: Necessity and Features
}

\author{
Irina Baturina ${ }^{1},{ }^{*}$ Tatiana Bukhtiyarova ${ }^{2}$, Irina Artamonova ${ }^{1}$ \\ ${ }^{1}$ Federal State Budgetary Educational Institution of Higher Education "Kurgan State University", Kurgan, Russia
${ }^{2}$ Russian Academy of National Economy and Public Administration under the President of the Russian Federation,
Chelyabinsk Branch, Chelyabinsk, Russia \\ *Email: baturina76@mail.ru
}

\begin{abstract}
This study aims to substantiate the necessity and study the specifics of the digitalisation of the agro-industrial complex. In modern conditions of organisation and management, the potential for economic growth is contained in the latest digital technologies, which contributes to increasing the accuracy and reliability of management decisions in any branch of the national economy. The economy of the agricultural sector is associated with a variety of technologies in agricultural production and a variety of production processes. The primary agricultural production resources (land, climate, etc.) are limited. Any increase in agricultural production of farm producers opens up soil quality problems, pollution of water bodies, increase in harmful emissions into the atmosphere, etc. Digital technologies in the agroindustrial complex through processing the received information allow users to optimise production and management processes. The use of digital technologies in the agro-industrial complex reduces the negative human impact on natural factors of production, thereby increasing the efficiency of management of this industry. Innovative production technologies provide a similar effect. Digitalisation and digital transformation of the agro-industrial complex are not the purposes of the activities of economic entities but act as part of the mechanism for optimising the potential of agricultural organisations. The methodological basis for this study was the scientific works of economists in the field of digitalisation of the economy in general and the agro-industrial complex in particular. Analytical, logical, monographic scientific methods were used to prepare this paper. The study results concluded that it is impossible to achieve high results in current economic conditions without introducing digital technologies in agricultural production.
\end{abstract}

Keywords: Digital economy, Agro-industrial complex, Digital platform, Digital agriculture, IT technologies, Agricultural producers, Transformation.

\section{INTRODUCTION}

The digitalisation of the economy as a whole and its particular sectors currently acts as one of the incentives for regulatory influence on the economic policy of economic entities at different levels. It is designed to interest domestic producers of agricultural products to develop high-tech resources and introduce IT technologies everywhere. Still, the implementation of this provision requires the state to assist in providing access to the Internet in remote areas of Russia, which will increase the availability of public services in the electronic form to $80 \%$ by 2025 .
The degree of development of digital technologies, their role in shaping the competitiveness of individual economic entities, countries, experts determine in the form of a catalyst for economic growth. Under presidential decree No. 474 on 21.07.2020, target indicators of digital transformation of the Russian economy by 2030 are "...the provision of "digital maturity" state control of key sectors of the economy, the social sphere: increase to $95 \%$ the proportion of the mass of socially important services rendered electronically, up to $97 \%$ - the share of households with Internet access; a fourfold increase in the volume of investments in the Russian solutions in the field of 
information technologies in comparison with the value of 2019" [1].

The concept of "Scientific and technological development of digital agriculture of the Russian Federation effectively notes that "...to increase the profitability of agricultural production as a result of the use of optimisation solutions in cost management, more efficient allocation of funds is possible based on the use of digital technologies in agriculture. The digital economy practice ensures a reduction in costs by at least $23 \%$." But it should be pointed out that the lag behind the world leaders (USA, Japan, Great Britain, Finland, Israel, etc.) in terms of readiness for digitalisation of the economy hinders the implementation of the national program due to the imperfection of the regulatory framework for regulating the digital economy and the low level of use of its technologies by domestic subjects [2].

The need to increase the quantitative and qualitative characteristics of the crop yield, minimising capital costs associated with a lack of financing of the agricultural sector, reducing labour intensity and increasing labour productivity in agrarian organisations, solving environmental problems, etc. determine the importance of digitalisation of the agro-industrial complex [3].

\section{METHODOLOGY AND THEORETICAL FOUNDATIONS OF THE STUDY}

The theoretical and methodological basis of the study was the scientific works of economists on modelling and the use of mathematical tools in the process of agricultural management.

When writing the article, the authors studied and analysed publications on the introduction of digital technologies in agricultural production, posted in open access on the official websites of electronic libraries on the Internet.

The practicality of using IT technologies in the agroindustrial complex is caused by the acceleration of the pace of development of the global information system and the growth of competitiveness of individual economic entities. Information technology and its processes are now the basis for making effective management decisions. The digital economy is considered in the form of particular economic activity, which is a crucial factor (resource) is data in digital format, processing of large volumes and using the results of the analysis, which, unlike traditional forms of management, helps to improve the effectiveness of the various types of production, technologies, processes, services $[3,4,5]$.
The domestic agro-industrial complex digitalisation history can be divided into several successive stages (Figure 1) [6].

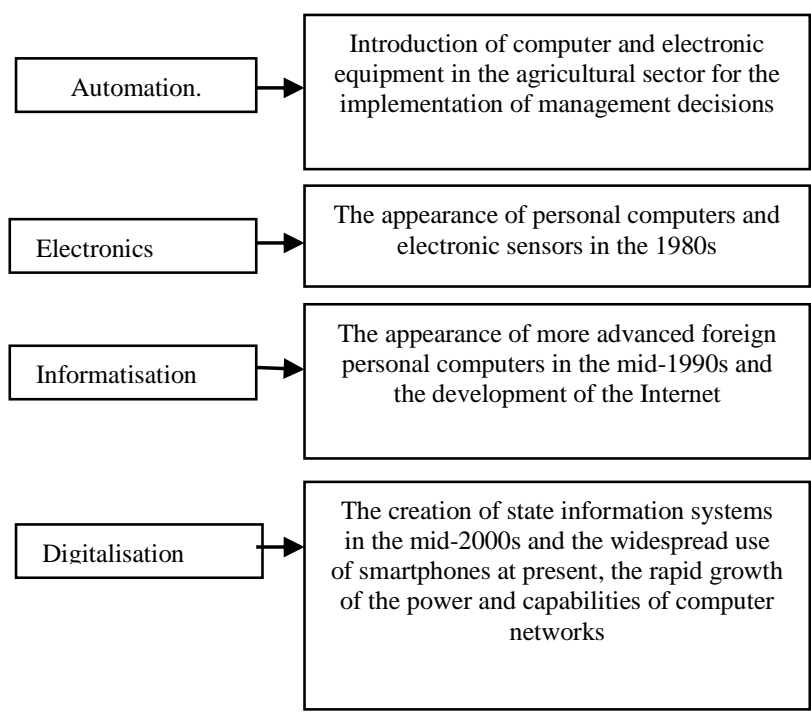

Figure 1 The evolution of the digital transformation of the agro-industrial complex.

From a technical point of view, digital platforms are the essential elements of the digital economy. They are being developed to increase the growth of production volumes of agricultural organisations by improving and optimising business processes with the help of innovative services. The process of creating a digital platform is based on the analysis of similar digital products already being implemented and determining trends in their development to form requirements for digital platforms in the agro-industrial complex [7].

The digital platform in the agro-industrial complex will allow:

- repeatedly use the information;

- economic activity will be limited only by the capabilities of the Internet;

- the competitiveness of an economic entity will depend not on its size but the technologies used.

The solution of problematic issues that hinder the effective digitalisation of the agro-industrial complex is an element of integrated and sustainable development of rural areas. The implementation of state measures to support the development of agriculture required organisational changes from the Ministry of Agriculture of the Russian Federation - the federal state budgetary institution "Analytical Centre of the Ministry of Agriculture of Russia" (AC MA) was created in the structure, responsible for the formation of a portfolio of digital solutions, information support for farmers about new opportunities, technologies and available practices [8]. 


\section{DISCUSSION AND RESULTS}

The digitalisation of the agro-industrial complex covers the entire life cycle of the manufactured product. The introduction of end-to-end digital technologies into agricultural production will reduce the costs of the state and economic entities, which will lead to the optimisation of the economic management mechanism of the agro-industrial complex. This statement is true because "... any information process, data processing algorithm in economic practice even has a dominant position concerning material forms of human activity" [5].

Global threats and challenges should be considered objective prerequisites for introducing digital technologies in agriculture. In this thesis, clarification is needed:

- the growth of demand for agricultural products in conditions of a disturbed balance between supply and demand itself leads to threats to the food security of countries;

- lack of stability in international food markets caused by high competition;

- social resistance to innovation and IT technologies, lack of qualified personnel;

- the globalisation of the agro-industrial complex causes the displacement of small agricultural producers from the market;

- mass application in the production of agricultural products GMO technologies [9].

Innovative digital technologies make it possible to compare the capabilities of farmers and consumers of agricultural products (nano- and biotechnology, genetic engineering) [10]. The use of IT technologies in the agro-industrial complex leads to the transformation of production technologies, the business's organisational structure, professional competencies, the organisation of relationships with contractors, etc. From our point of view, it is correct to highlight not only its positive but also negative consequences. The first is the emergence of new products and services, the growth of agricultural turnover, labour productivity, improvement of product quality, etc. Negative consequences are most often attributed to: the probability of unemployment and the associated risk of income reduction, the disappearance of individual professions and entire sectors of the economy, the aggravation of problems of economic, food and industrial security $[3,4,5,11]$.

The authors agree with the view that the transition to a digital economy in agriculture allows solving the "three-pronged task": "...a single digital market is formed by using digital platforms, with underlying conditions" [12]; the formation of a global digital marketplace eliminates the barriers (political, cultural, economic, etc.), using free movement in the virtual space of economic agents, products, capital, etc.; the build for all levels of management in agribusiness digital platforms of the ecosystem of the digital economy [5].

Expanding the use of IT technologies will provide:

- the use of living organisms in the production process (the connection of technologies with animals, plants and people);

- the variety and different complexity of agricultural production processes that require the use of digital technologies;

- the controlled parameters are distributed over large areas and are random, etc. [7].

It should be borne in mind that the transition of agriculture to digital technologies is an integral part of the national strategy. This is evident in the federal project "Digital Agriculture", currently being implemented to modernise and improve its efficiency. The project will double labour productivity in the country's agriculture by 2024. The FoodNet and AeroNet roadmaps of the National Technology Initiative (NTI) also aim to implement the concept of "smart" agriculture, attracting grants and returnable investments in the amount of 3.3 billion rubles. According to forecasts of the Ministry of Agriculture of Russia, the introduction of information technologies in the agro-industrial complex will reduce the cost of grain production by 1513.3 rubles/ton, the growth of total agricultural production as a result of digitalisation may reach 361.4 billion rubles. The researchers note that agriculture has a significant potential for introducing and developing digitalisation. Expert estimates of the Ministry of Agriculture of Russia indicate that the domestic market of IT technologies in this industry is approximately 360 billion rubles, and its projected growth by 2026 is at least 5 times $[2,6]$.

The main problem of the spread of IT technologies in the agro-industrial complex is the insufficient level of awareness of small and medium-sized businesses in this industry about new developments and technologies. The second most important problem is the shortage of agricultural producers' funds for digitalisation. The Digital Agriculture program regulates the digital transformation of the agro-industrial complex in Russia. The sources of funds for financing the implementation of this program should be: state programs, extrabudgetary funds and funds of agricultural producers, i.e., in fact, we are talking about public-private partnership [11]. In addition, the solution to the problem of financing digital innovations can be the formation of special services, the primary function of which will be the introduction of digital technologies and monitoring their use [12]. 
The Russian economy is characterised by the socalled "island" digitalisation, in which IT technologies are used by individual economic entities. The lack of software product developers of complete databases that consider the specifics of the agro-industrial complex implies processing large amounts of information and obtaining accurate analytical reports necessary for optimising decisions of each business process.

This requires a well-developed information and communication infrastructure (information resources, integration business platforms, digital environment, highly qualified personnel). Based on these elements, a digital ecosystem can be created in which each subject plays two roles - a client and a data server $[6,10,13]$.

The purpose of digitalisation is to form a unified information space containing up-to-date databases on a wide variety of issues and a variety of information and telecommunication systems. The effectiveness of the digitalisation of the agro-industrial complex can be increased by creating a marketplace (electronic trading platform) for the sale of agricultural products to intermediaries and end consumers. Some components of the digital economy can be used to monitor the state and use of land resources, crops, and various financial and economical operations [13-19].

\section{CONCLUSION}

The authors of the article adhere to the point of view that the effective use of IT technologies in agriculture is possible only with the availability of a sufficient amount of accurate and objective data on all objects of the agroindustrial complex, which requires a complete inventory of the entire industry and modernisation of the system of state information support for agriculture.

Without the introduction of digital technologies, it is impossible to increase the efficiency and sustainability of the functioning of the agro-industrial complex through a change in the quality of management of individual economic entities and the industry as a whole. Changes in the management process are based on innovative production processes and the use of up-todate information about the state and prospects of agricultural development. The use of modern technologies in the agro-industrial complex makes it possible to optimise agricultural production conditions, labour productivity, production costs, maintenance and preservation of soil and environmental quality.

\section{REFERENCES}

[1] Decree of the President of the Russian Federation on July 21, 2020, No. 474 "On the National Development Goals of the Russian Federation for the period up to 2030" [Ukaz Prezidenta RF ot 21 iyulya 2020 g. N $474 \ll O$ nacional'nyh celyah razvitiya Rossijskoj Federacii na period do 2030 goda»]. Retrieved from: https://base.garant.ru/74404210/\#ixzz7CxBiZLwu

[2] Passport of the national project National Program "Digital Economy of the Russian Federation" (approved by the minutes of the meeting of the Presidium of the Presidential Council for Strategic Development and National Projects on June 4, 2019 N 7) [Pasport nacional'nogo proekta Nacional'naya programma «Cifrovaya ekonomika Rossijskoj Federacii» (utv. protokolom zasedaniya prezidiuma Soveta pri Prezidente Rossijskoj Federacii po strategicheskomu razvitiyu i nacional'nym proektam ot 4 iyunya 2019 g. N 7)]. Retrieved from: https://base.garant.ru/72296050/\#ixzz7CxBWsp68

[3] N.V. Karpuzova, Methodological aspects of the formation of the information sphere of the agroindustrial complex economy [Metodologicheskie aspekty formirovaniya informacionnoj sfery ekonomiki APK], Moscow Economic Journal [Moskovskij ekonomicheskij zhurnal], No. 3, 2018, URL:

https://cyberleninka.ru/article/n/metodologicheskie -aspekty-formirovaniya-informatsionnoy-sferyekonomiki-apk

[4] Decree of the President of the Russian Federation No. 203 on May 9, 2017 "On the Strategy for the Development of the Information Society in the Russian Federation for 2017-2030" [Ukaz Prezidenta RF ot 9 maya 2017 g. № 203 «O Strategii razvitiya informacionnogo obshchestva $\mathrm{V}$ Rossijskoj Federacii na 2017 - 2030 gody»]. Retrieved from: https://base.garant.ru/71670570/

[5] TN. Astakhova, M.O. Kolbanev, A.A. Shamin, Decentralised Digital Platform of Agriculture [Decentralizovannaya cifrovaya platforma sel'skogo hozyajstva], Bulletin of NNSEEU [Vestnik NGIEI], No. 6(85), 2018. URL: https://cyberleninka.ru/article/n/detsentralizovanna ya-tsifrovaya-platforma-selskogo-hozyaystva

[6] S.B. Ognivtsev, The concept of the digital platform of the agro-industrial complex [Koncepciya cifrovoj platformy agropromyshlennogo kompleksa], International Agricultural Journal [MSKH], No. 2, 2018. URL: https://cyberleninka.ru/article/n/kontseptsiyatsifrovoy-platformy-agropromyshlennogokompleksa

[7] N.A. Mironova, Digital economy and digital platforms in the agro-industrial complex [Cifrovaya ekonomika i cifrovye platformy $\mathrm{v}$ APK], Moscow Economic Journal [Moskovskij 
ekonomicheskij zhurnal], No. 7, 2019. URL: https://cyberleninka.ru/article/n/tsifrovaya-

ekonomika-i-tsifrovye-platformy-v-apk

[8] Retrieved from: https://www.mcxac.ru/

[9] T.I. Bukhtiyarova, O.N. Mikhailyuk, I.N. Baturina, Digitalisation of agriculture is one of the directions of economic growth [Cifrovizaciya sel'skogo hozyajstva - odno iz napravlenij ekonomicheskogo rosta], Theory and Practice of World Science [Teoriya i praktika mirovoj nauki] 4 (2021) 10-13.

[10] S.A. Mulyarets, Specifics and problems of digital transformation of enterprises of the Russian agroindustrial complex [Specifika i problemy cifrovoj transformacii predpriyatij rossijskogo agropromyshlennogo kompleksa], Innovations and investments [Innovacii i investicii], No. 4, 2021. URL: https://cyberleninka.ru/article/n/spetsifika-iproblemy-tsifrovoy-transformatsii-predpriyatiyrossiyskogo-agropromyshlennogo-kompleksa

[11] S.A. Chernikova, Directions of digital economy development in the agro-industrial complex [Napravleniya razvitiya cifrovoř ekonomiki v agropromyshlennom komplekse], Moscow Economic Journal [Moskovskij ekonomicheskij zhurnal], No. 7, 2019. URL: https://cyberleninka.ru/article/n/napravleniyarazvitiya-tsifrovoi-ekonomiki-vagropromyshlennom-komplekse

[12] I.V. Kovaleva, Digitalisation of agriculture as a strategic element of industry management [Cifrovizaciya sel'skogo hozyajstva kak strategicheskij element upravleniya otrasl'yu], Economics and Business: Theory and Practice [Ekonomika i biznes: teoriya i praktika], No. 3-1, 2019.

URL:

https://cyberleninka.ru/article/n/tsifrovizatsiyaselskogo-hozyaystva-kak-strategicheskiy-elementupravleniya-otraslyu

[13] A.V. Plotnikov, The role of the digital economy for the agro-industrial complex [Rol' cifrovor ekonomiki dlya agropromyshlennogo kompleksa], Moscow Economic Journal [Moskovskij ekonomicheskij zhurnal], No. 7, 2019. URL: https://cyberleninka.ru/article/n/rol-tsifrovoiekonomiki-dlya-agropromyshlennogo-kompleksa

[14] A.N.Semin, M.M. Kislitsky, I.Yu. Agnayeva, V.Yu. Vorona, Domestic experience of the formation of the local level of rural economy through digital technologies [Otechestvennyj opyt formirovaniya lokal'nogo urovnya sel'skoj ekonomiki sredstvami cifrovyh tekhnologij], STAGE [ETAP], No. 6, 2018. URL: https://cyberleninka.ru/article/n/otechestvennyyopyt-formirovaniya-lokalnogo-urovnya-selskoyekonomiki-sredstvami-tsifrovyh-tehnologiy

[15] S.B. Ognivtsev, Digitalisation of the economy and the economy of digitalisation of agriculture [Cifrovizaciya ekonomiki i ekonomika cifrovizacii APK], International Agricultural Journal [MSKH], No. 2, 2019. URL: https://cyberleninka.ru/article/n/tsifrovizatsiyaekonomiki-i-ekonomika-tsifrovizatsii-apk

[16] A.A. Aletdinova, Innovative development of the agricultural sector based on digitalisation and creation of technological platforms [Innovacionnoe razvitie agrarnogo sektora na osnove cifrovizacii i sozdaniya tekhnologicheskih platform], Innov: electronic scientific journal [Innov: elektronnyj nauchnyj zhurnal], No. 4(33), 2017. URL: https://cyberleninka.ru/article/n/innovatsionnoerazvitie-agrarnogo-sektora-na-osnove-tsifrovizatsiii-sozdaniya-tehnologicheskih-platform

[17] R. Bukh, R. Defining Heeks, Conceptualising and Measuring the Digital Economy, Global Development Institute working papers, No. 68, 2017. URL: https://diodeweb.files.wordpress.com/

[18] I.P. Chupina, The competitiveness of products as the object of targeted strategic development of an economic entity, Eastern European Scientific Journal 1 (2016) 59-62.

[19] S. Cheah, S. Wang, Big data-driven business model innovation by traditional industries in the Chinese Economy, J. Chin. Econ. Foreign Trade Stud 10 (2017) 229-251. 